The Bangladesh Veterinarian (2011) 28(2) : 85 - 94

\title{
Comparative performance of different regional native sheep in Bangladesh
}

\author{
M. R. Hassan ${ }^{1 *}$ and M. A. I. Talukder \\ Goat and Sheep Production Research Division, Bangladesh Livestock Research Institute, \\ Savar, Dhaka-1341, Bangladesh
}

\begin{abstract}
This study was undertaken to investigate the performance of native sheep in Bangladesh. Data were collected during 2004-2010 from sheep of the Barind, Jamuna and Coastal areas. The phenotypic characteristics did not differ significantly, but ears were shorter in Barind than in Jamuna and Coastal sheep. The coat colour was $45 \%$ white, $26 \%$ brown, $24 \%$ white brown and 3\% black brown in Barind and Jamuna sheep, but white $(70 \%)$ and white brown (30\%) in Coastal sheep. Differences were not significant for age at first heat, age at first pregnancy and age at first lambing. Days open and post-partum ewe weight were significantly $(\mathrm{P}<0.01)$ different. Onset of post-partum heat, lambing interval, gestation length, number of services per pregnancy, litter size and placental weight did not differ significantly. Birth weight was significantly $(\mathrm{P}<0.05)$ higher in Coastal sheep than in Barind and Jamuna. Higher $(\mathrm{P}<0.05)$ wool yield was obtained in Coastal sheep and in the summer. Though the wool was coarse and hairy, wool from Coastal sheep had more $(\mathrm{P}<0.05)$ bends per inch, and was finer. Diarrhoea, pneumonia in lambs and skin diseases were the most common diseases in all sheep. Though sheep from the different areas had similar performance, better reproductive performance was obtained in the Barind sheep. (Bangl. vet. 2011. Vol. 28, No. 2, 85 - 94)
\end{abstract}

\section{Introduction}

Sheep are important in Bangladesh, providing meat and wool. During the last twelve Years sheep population increased 2.5 times, with annual growth rate of $5 \%$ (BBS, 2008). There are 2.7 million sheep (BBS, 2008), of which $32 \%$ are reared in three ecological zones. Barind, Jamuna basin and Coastal areas. Most of the sheep are indigenous, with few crossbreds (Bhuiyan, 2006) and are capable of bi-annual lambing and multiple births. The fecundity gene (Booroola) in Australian Merino may be derived from this Bengal line (Piper and Bindon, 1996). Native sheep (Ovis aries) might have originated from the wild Urial (Ovis orientalis vignei) of Asia.

Under traditional feeding systems, the sheep are raised on harvested or fallow lands, roads, and canal sides (Sultana et al., 2010) and also graze on aquatic weeds and grass in knee-deep water.

No other domestic animals are capable of existing on such feed. With their small

\footnotetext{
1Department of Animal Science, Chonbuk National University, South Korea

*Corresponding author:- E-mail: mdrakibulhassan@gmail.com
} 
muzzles and split upper lips they can nibble tiny blades of vegetation, which cannot be eaten by bigger animals (Banerjee, 1989). They average 15 to $25 \mathrm{~kg}$ live weight (Mukherjee, 2000) and are adapted to hot humid climate. Their body is grey, with black or white patches, and the face, ear and feet are mostly light black. Wool is coarse with high medullation. Sheep are tolerant to disease in the humid and sub-humid tropics. These animals were neglected in the past, therefore there is limited information regarding the potential of native sheep. But the Bangladesh government is emphasising the raising of sheep. The present study was undertaken to determine the phenotypic characteristics, reproductive performance, growth and wool production of sheep in different areas of Bangladesh.

\section{Methods and Materials}

Sheep were purchased in 2003 from three areas of Bangladesh, Barind (Naogaon, Rajshahi, Chapi Nababganj), Jamuna river basin (mostly in Tangail) and Coastal (Noakhali) areas, and reared in the Goats and Sheep production research farm, Bangladesh Livestock Research Institute, Dhaka, Bangladesh. The breeding programme was designed so that the purity of animals from a particular area was maintained. Animals were housed in slatted floor permanent houses. Rams were kept separately from ewes to avoid unplanned mating. Animals were allowed to graze for 6-7 hours except during rain and supplemented with concentrate $(17 \% \mathrm{CP}, 11 \mathrm{MJ} / \mathrm{kg}$ DM) $200 \mathrm{~g} /$ animal/day and seasonally available green and dry fodder. Ewes were kept in lambing pens under close observation for three to four days prior to the expected date of parturition. At lambing, lambs and ewes were weighed, and the lambing date, sex and parity of each lamb were recorded. Wool was sheared both summer and winter and yield was measured by digital platform balance (Kern, Germany). The wool was sorted, graded and cleaned. Staple length was measured. The wool fibres were observed and counted with the help of a projection microscope at 500-power magnification. Disease was recorded daily on the basis of clinical signs and laboratory examinations, and causes of mortality were observed by clinical signs, post-mortem examination and laboratory tests. Necessary treatments were given against specific diseases according to the suggestion of the veterinary surgeons. Treatments were provided regularly against internal and external parasites. All animals were dipped in $0.1 \%$ malathion solution monthly. Sheep with ill health, stunted growth, repeat breeding, or severe skin diseases were culled.

Phenotypic characteristics studied were body length, heart girth, wither height, hip height, head length and breadth, ear length, udder length and breadth, testis length, teat length and breadth, tail length and breadth, body depth and body weight and nose length. Reproductive traits were age at first heat (AFH), age at first pregnancy (AFP), age at first lambing (AFL), onset of post-partum heat (OPPH), days open (DO: number of days between lambing to conception), lambing interval (LI), gestation length (GL), number of services per pregnancy (NSP), litter size (LS), postpartum ewe weight (PEW) and birth weight of lamb (BWL). 


\section{Statistical analysis}

The statistical analysis of the data was performed using general linear model procedure of SPSS 11.5 software program. The differences between treatment means were examined using least significant difference (LSD).

The data on reproductive traits were analysed using the statistical model

$$
Y_{i j k l}=\mu+Y_{i}+G_{j}+L_{k}+(G \times L) j k+e ~ i i j k l
$$

where, $\mathrm{Y}_{\mathrm{ijkl}}=$ an observed reproductive trait,

$\mu=$ the overall mean,

$Y_{i}=$ effect of the year of birth ( $\left.i=2004-2010\right)$,

$\mathrm{G}_{\mathrm{j}}=$ effect of location of sheep $(\mathrm{j}=$ Jumuna, Barind and Coastal area),

$\mathrm{L}_{\mathrm{k}}=$ effect of the lactation number; $(\mathrm{k}=1-3)$,

$(G \times L) j k=$ effect of interaction between $j$-th location and $k$-th lactation number,

e $\mathrm{ijkl}=$ random error, assumed to be normally distributed with mean zero and common variance.

\section{Results and Discussion}

Phenotypic characteristics

The phenotypic characteristics are in Table 1 . The coat colour was $45 \%$ white, $26 \%$ brown, $24 \%$ white-brown and 3\% black-brown. The differences between areas were not significant, except ears were significantly $(\mathrm{P}<0.05)$ shorter in Barind than Jamuna and Coastal areas. Gopal and Prasad (2007) stated that the overall least square means for body length, height at withers, chest girth and tail lengths were 82.9, 83.9, 85.1 and $53.3 \mathrm{~cm}$ in adult Muzaffarnagari sheep in India, which is higher than the present findings.

\section{Reproductive characteristics}

The reproductive characteristics are in Tables 2 and 3. The differences in reproductive characteristics were non-significant between areas except days open, post partum ewe weight and birth weight of lamb.

Age at first heat, pregnancy and lambing

Ages at first heat, first pregnancy and lambing did not differ significantly between areas (Table 2). Barind sheep matured earliest, but this difference was not significant.

Onset of post-partum heat, days open and lambing interval

Onset of post-partum heat and placenta weight did not differ significantly between areas (Table 3). Post-partum heat occurred later (37.5 days) in Coastal but earlier (30.5 days) in Jamuna areas. Though the lambing interval did not differ 
significantly, days open was significantly $(\mathrm{P}<0.05)$ higher in Coastal than the other two areas. Consequently, post-partum weight of ewes was remarkably $(\mathrm{P}<0.05)$ higher in Coastal and Barind than Jamuna areas, maybe due to the body size. Poonia (2008) found in Munjal sheep in India that the mean age at first lambing, weight at first lambing and lambing interval were $530.5 \pm 12.4$ days, $35.4 \pm 0.6 \mathrm{~kg}$ and $247.7 \pm 4.9$ days, respectively, higher than the present findings.

Table 1. Phenotypic characteristics of native sheep

\begin{tabular}{|c|c|c|c|c|c|}
\hline \multirow{2}{*}{ Parameters $(\mathrm{cm})$} & \multicolumn{3}{|c|}{ Region } & \multirow[t]{2}{*}{ SED } & \multirow{2}{*}{$\begin{array}{c}\text { Level of } \\
\text { significance }\end{array}$} \\
\hline & Jamuna river basin & Barind & Coastal & & \\
\hline Body length & 41.5 & 43.4 & 45.9 & 1.9 & NS \\
\hline Heart girth & 62.7 & 61.5 & 64.9 & 1.0 & NS \\
\hline Weather height & 51.7 & 52.9 & 53.5 & 0.7 & NS \\
\hline Hip height & 51.9 & 52.5 & 52.9 & 0.3 & NS \\
\hline Head length & 16.0 & 16.1 & 16.3 & 0.3 & NS \\
\hline Head breath & 7.7 & 7.4 & 7.8 & 0.2 & NS \\
\hline Ear length & $8.4^{\mathrm{a}}$ & $3.2^{\mathrm{b}}$ & $8.4^{\mathrm{a}}$ & 3.7 & $\mathrm{P}<0.05$ \\
\hline Udder length & 6.8 & 6.8 & 6.9 & 0.4 & NS \\
\hline Udder breath & 7.1 & 7.0 & 7.1 & 0.5 & NS \\
\hline Testis length & 10.7 & 11.0 & 10.7 & 0.1 & NS \\
\hline Tail length & 12.0 & 11.5 & 12.0 & 0.2 & NS \\
\hline Tail breath & 4.2 & 4.3 & 4.21 & 0.2 & NS \\
\hline Body weight (kg) & 41.2 & 40.6 & 41.6 & 1.0 & NS \\
\hline Body depth & 3.0 & 3.0 & 3.1 & 0.4 & NS \\
\hline Nose & 17.0 & 16.9 & 17.8 & 0.2 & NS \\
\hline
\end{tabular}

NS Not significant; a, b, c Mean values having different superscripts in a row differ significantly $(\mathrm{P}<0.05)$

Table 2. Reproductive traits of ewes from three different areas

\begin{tabular}{l|c|c|c|c}
\hline \multicolumn{1}{c|}{ Parameters (day) } & \multicolumn{3}{|c|}{ Region } & $\begin{array}{c}\text { Level of } \\
\text { significance }\end{array}$ \\
\cline { 2 - 4 } & Jumuna & Barind & Coastal & NS \\
\hline Age at first heat (AFH) & $239.9 \pm 35.5$ & $224.4 \pm 24.3$ & $279.0 \pm 50.3$ & NS \\
Age at first pregnancy (AFP) & $277.0 \pm 104.9$ & $264.7 \pm 49.4$ & $292.3 \pm 47.5$ & NS \\
Age at first lambing (AFL) & $409.8 \pm 75.0$ & $389.9 \pm 43.0$ & $439.5 \pm 58.3$ & . \\
\hline
\end{tabular}

Gestation length and number of service per pregnancy

Gestation length and number of services per pregnancy did not differ significantly between areas (Table 3). Gestation was longer in Jamuna sheep. Coastal 
sheep required more services (1.4) for successful pregnancy. Husain and Amin (2003) reported that the gestation period of Native sheep was 149.0 days. Rahman and Huq (1976) reported gestation length in Native, Native $\times$ Lohi grade I and Native $\times$ Lohi grade II was $143.2 \pm 5.5,149.2 \pm 5.8$ and $134.2 \pm 5.3$ days, respectively.

\section{Litter size}

Litter size did not differ significantly among the three areas (Table 3) but was higher in Jamuna area. Nimbkar et al. (2002) found that the average litter size of Garole $x$ Deccani sheep was 1.6, which agrees with the present findings. Bhuiyan and Curran (1991) reported that litter size of Romney marsh ewes differed with age and year. Rahman and Huq (1976) found in Native ewes $48 \%$ single and $52 \%$ multiple births. Sharma et al. (1999) noted average litter size of Garole was 1.7 with $40 \%$ single, $53 \%$ twins, 5\% triplets and 1.7\% quadruplets. However, Bose et al. (1999) recorded litter size in Garole as 1.7 with percentage of single, twin, triplet and quadruplet is 42 , 43, 15 and 0.2, respectively. According to Pan et al. (2004) average lambing frequency was 1.6 - 1.9, but Singh and Bohra (1996) found litter size at first lambing in Garole was 2 and at subsequent lambing 2.3. Banerjee (2008) reported litter size of 1.9 in native Bengal Garole.

Table 3. Reproductive traits of different type's of ewe

\begin{tabular}{|c|c|c|c|c|}
\hline \multirow[t]{2}{*}{ Parameters } & \multicolumn{3}{|c|}{ Region } & \multirow{2}{*}{\begin{tabular}{|c} 
Level of \\
sig.
\end{tabular}} \\
\hline & Jamuna & Barind & Coastal & \\
\hline Onset of post-partum heat (OPPH; day) & $30.5 \pm 3.9$ & $32.0 \pm 4.1$ & $37.5 \pm 4.0$ & NS \\
\hline Days open (DO; day) & $33.6 \pm 6.0^{\mathrm{b}}$ & $36.6 \pm 6.8^{\mathrm{b}}$ & $58.0 \pm 7.8^{\mathrm{a}}$ & $\mathrm{P}<0.05$ \\
\hline Lambing interval (LI; days) & $188.6 \pm 6.0$ & $189.5 \pm 5.5$ & $204.3 \pm 7.7$ & NS \\
\hline Gestation length (GL; days) & $152.8 \pm 3.8$ & $145.0 \pm 4.1$ & $146.6 \pm 5.4$ & NS \\
\hline Number of services/pregnancy (NSP) & $1.3 \pm 0.1$ & $1.3 \pm 0.1$ & $1.4 \pm 0.1$ & NS \\
\hline Litter size (LS) & $1.8 \pm 0.1$ & $1.7 \pm 0.1$ & $1.6 \pm 0.2$ & NS \\
\hline Post-partum ewe weight (PEW; kg) & $17.8 \pm 0.4^{\mathrm{b}}$ & $19.2 \pm 0.4^{\mathrm{a}}$ & $19.6 \pm 0.6^{\mathrm{a}}$ & $\mathrm{P}<0.01$ \\
\hline Placenta weight (PW; gm) & $355.5 \pm 14.1$ & $335.9 \pm 15.5$ & $331.0 \pm 18.6$ & NS \\
\hline
\end{tabular}

NS Not significant; $\mathrm{P}<0.01$ Significant at $1 \%$ level of probability; a, b, c Mean values having different superscripts in a row differ significantly $(\mathrm{P}<0.05)$

\section{Lambing interval}

Lambing interval did not differ significantly between areas, being 188.6, 189.5 and 204.3 days in Jamuna, Barind and Coastal sheep, which indicates that three lambings in two years are attainable. Husain and Amin (2003) reported that lambing interval of native sheep was 253.0 days. Nimbkar et al. (2002) found in Deccani sheep in India that the average lambing interval was $264.0 \pm 81.0$ days, higher than the present findings. Poonia (2008) found that the lambing interval was $247.7 \pm 4.9$ days, also higher than the present findings. Rahman and Huq (1976) reported the lambing 
interval of Native sheep, Native $x$ Lohi grade I, and Native $x$ Lohi grade II was $253.9 \pm$ 82.6 days, $294.1 \pm 92.7$ and $484.6 \pm 53.8$ days.

\section{Lamb birth weight}

Lamb birth weight differed significantly $(\mathrm{P}<0.05)$ between areas (Table 4$)$. Irrespective of sex, lamb birth weight was significantly $(\mathrm{P}<0.05)$ higher in Coastal area followed by Barind and Jamuna areas. Sani et al. (1999) found that male sheep had slightly higher body weight than female sheep of same ages. Husain and Amin (2003) reported that birth weight of native sheep was $1.2 \mathrm{~kg}$.

Table 4 . Birth weight $(\mathrm{kg})$ of native sheep according to sex

\begin{tabular}{l|l|c|c|c|c}
\hline Litter size & Sex & \multicolumn{3}{|c|}{ Birth weight $(\mathrm{kg})$} & $\begin{array}{c}\text { Level of } \\
\text { significant }\end{array}$ \\
\cline { 3 - 5 } & & Jumuna river basin & Barind & Coastal & \\
\hline Single & Male & $1.5 \pm 0.1^{\mathrm{b}}$ & $1.4 \pm 0.0^{\mathrm{b}}$ & $1.9 \pm 0.0^{\mathrm{a}}$ & $\mathrm{P}<0.05$ \\
& Female & $1.1 \pm 0.2^{\mathrm{b}}$ & $1.0 \pm 0.0^{\mathrm{b}}$ & $1.4 \pm 0.0^{\mathrm{a}}$ & $\mathrm{P}<0.05$ \\
\multirow{3}{*}{ Twin } & Male & $1.2 \pm 0.1^{\mathrm{c}}$ & $1.5 \pm 0.0^{\mathrm{b}}$ & $1.6 \pm 0.1^{\mathrm{a}}$ & $\mathrm{P}<0.05$ \\
& Female & $1.2 \pm 0.1^{\mathrm{b}}$ & $1.4 \pm 0.0^{\mathrm{b}}$ & $1.5 \pm 0.3^{\mathrm{a}}$ & $\mathrm{P}<0.05$ \\
\multirow{2}{*}{ Triplet } & Male & $1.3 \pm 0.1$ & $1.4 \pm 0.1$ & $1.3 \pm 0.0$ & $\mathrm{NS}$ \\
& Female & $1.3 \pm 0.1^{\mathrm{b}}$ & $1.2 \pm 0.1^{\mathrm{b}}$ & $1.5 \pm 0.0^{\mathrm{a}}$ & $\mathrm{P}<0.05$ \\
\hline
\end{tabular}

NS Not significant; a, b, c Mean values having different superscripts in a row differ significantly $(\mathrm{P}<0.05)$

\section{Wool yield}

The average wool production per cutting and the annual wool production of native sheep was significantly $(\mathrm{P}<0.05)$ higher in Coastal than Barind and Jamuna areas. Wool production was higher in the summer than in winter (Table 5). Thus, the Coastal sheep had higher body weight and wool production. In India, Khan et al. (2003) found that wool production was $1.3 \mathrm{~kg} /$ year in Tirahi breed of sheep, higher than the present findings.

Table 5. Wool production of native sheep from different areas

\begin{tabular}{l|c|c|c|c}
\hline \multirow{2}{*}{ Season } & \multicolumn{3}{c|}{ Wool yield $(\mathrm{gm})$} & $\begin{array}{c}\text { Level of } \\
\text { significance }\end{array}$ \\
\cline { 2 - 5 } & Jamuna region & Barind region & Coastal region & \\
\hline Summer (April) & $415.4^{\mathrm{b}} \pm 8.9$ & $440.0^{\mathrm{a}} \pm 14.1$ & $463.6^{\mathrm{a}} \pm 16.0$ & $\mathrm{P}<0.05$ \\
Autumn (November) & $318.3^{\mathrm{b}} \pm 63.4$ & $410.7^{\mathrm{a}} \pm 60.3$ & $388.5^{\mathrm{a}} \pm 50.2$ & $\mathrm{P}<0.05$ \\
Yearly total & $733.6^{\mathrm{c}} \pm 36.1$ & $810.7^{\mathrm{b}} \pm 10.2$ & $852.9^{\mathrm{a}} \pm 33.1$ & $\mathrm{P}<0.05$ \\
\hline
\end{tabular}

a, b, c Mean values having different superscripts in a row differ significantly $(\mathrm{P}<0.05)$

The wool quality parameters of native sheep are shown in Table 6. The staple length of native sheep did not differ significantly between areas. The number of 
crimps per inch was significantly $(\mathrm{P}<0.05)$ higher in Coastal than Jamuna and Barind areas. Though the major proportion of wool was hairy in all sheep, a significantly $(\mathrm{P}<0.05)$ higher proportion of fine wool was in the Coastal sheep. This may be due to crossing of Coastal sheep with other exotic breed.

Bose et al. (1999) showed that wool of Garole was extremely coarse, hairy and not very dense. Sharma et al. (1999) observed average annual adult wool yield from Garole sheep procured from Sundarban area was $179 \mathrm{~g}$ and was for rough carpet use. Singh and Bohra (1996) reported that average wool yield was 150g per shearing, lower than the present findings, which may be due to the body size. Prasad (1997) reported average annual production of wool per sheep was around $300 \mathrm{~g}$ and average fibre diameter, medullation, staple length and crimp/cm of Garole sheep were $67.8 \mu$, $75.5 \%, 5.1 \mathrm{~cm}$ and 2.1, respectively. On the other hand, Pan and Sahoo (2003) and Pan et al. (2004) recorded that Garole could produce approximately $400 \mathrm{~g}$ greasy fleece annually and fibre diameter, medullation and fibre length were $53 \mu, 79 \%$ and $5 \mathrm{~cm}$, respectively.

Table 6. Wool quality parameters from different region

\begin{tabular}{lcc|c|c}
\hline \multicolumn{1}{c|}{ Parameter } & Jamuna & Barind & Coastal & Significance \\
\hline Staple length (cm) & $7.21 \pm 1.12$ & $7.26 \pm 2.12$ & $7.95 \pm 1.25$ & NS \\
Crimp (bend/inch) & $2.34^{\mathrm{b}} \pm 0.33$ & $2.35^{\mathrm{b}} \pm 0.18$ & $2.75^{\mathrm{a}} \pm 0.45$ & $\mathrm{P}<0.05$ \\
Wool (\%) & & & & \\
Fine & $15.31^{\mathrm{b}} \pm 4.32$ & $16.32^{\mathrm{b}} \pm 5.40$ & $19.60^{\mathrm{a}} \pm 4.30$ & $\mathrm{P}<0.05$ \\
Hetero & $8.17 \pm 3.19$ & $7.35 \pm 3.11$ & $10.27 \pm 6.45$ & NS \\
Hairy & $76.52^{\mathrm{b}} \pm 7.37$ & $76.33^{\mathrm{b}} \pm 9.14$ & $70.13^{\mathrm{a}} \pm 8.29$ & $\mathrm{P}<0.05$ \\
\hline
\end{tabular}

a, $b$ Mean value with different superscripts within rows differ significantly at $\mathrm{P}<0.05$

\section{Diseases and mortality}

The average lamb mortality of Native sheep was $12.4 \%, 7.0 \%$ in July - October, $17.6 \%$ in November - February and $12.5 \%$ in March - May. In India, Nimbkar et al. (2002) in Garole sheep found that the average lamb mortality was $13.8 \%$, similar to the present findings. Diarrhoea, respiratory disorder, bloat, lice and skin disease were the most common diseases (Table 7). From birth to puberty, diarrhoea and pneumonia were the most common problems in all areas. In adult sheep, incidence of parasitic infestation was higher in Coastal than in Barind and Jamuna areas. On the other hand, highest alopecia (14.2\%) was in Coastal but conjunctivitis was more common in Barind $(7.5 \%)$ areas. The incidence of other diseases was similar in all areas.

Hoque and Mollah (1972) found that native sheep commonly suffer from lice infestation. Nooruddin et al. (1988) found lice infestation in $58 \%$ of sheep, dirty fleece in $18 \%$, psoroptic mange and mycotic dermatitis in $12 \%$, and other skin diseases in $11 \%$. Sheep were not affected by peste des petits ruminants. Most of the diseases occurred in the rainy season and lambs were mostly affected. Garole sheep are 
considerably more resistant to the roundworm Haemonchus contortus as well as to typical liver fluke (Nimbkar et al., 2002). Banerjee (2008) mentioned that Garole sheep are resistant to internal parasites, liver fluke and bacterial and viral diseases. Pan et al. (2004) recorded no trematode infection in Garole sheep. The incidence of gastrointestinal tract infection was 55\%, and that of abortion, repeat breeding, placental retention and post-partum mortality was 7.8, 9.3, 2.6 and $14.1 \%$, respectively.

Table 7. Incidence of sheep diseases in different areas

\begin{tabular}{l|c|c|c}
\hline \multirow{2}{*}{ Name of the disease } & \multicolumn{3}{|c}{ Region } \\
\cline { 2 - 4 } & $\begin{array}{c}\text { Jumuna } \\
\text { river basin }\end{array}$ & Barind & Coastal \\
\hline Diarrhoea & 23.1 & 15.5 & 13.7 \\
Pneumonia in lamb & 15.4 & 16.4 & 13.1 \\
Shortage of mother milk and weakness in lamb & 21.5 & 14.2 & 13.2 \\
Parasitic disease & 17.4 & 18.2 & 23.2 \\
Alopecia & 11.2 & 8.4 & 14.2 \\
Bloat & 1.9 & 5.7 & 6.2 \\
Conjunctivitis & 3.5 & 7.5 & 6.8 \\
Urolithiasis & 3.2 & 4.1 & 3.6 \\
Enterotoxaeimia & 1.2 & 2.9 & 1.7 \\
Tetanus & 1.4 & 0.6 & - \\
Obstetrical diseases & 0.9 & 1.3 & 1.7 \\
Sub-clinical mastitis & 3.4 & 3.2 & 3.0 \\
Udder problem & 2.7 & 1.4 & 2.5 \\
Pregnancy toxaemia & 0.2 & - & - \\
Foot rot & - & 0.6 & - \\
Unknown diseases & 2.4 & - & 1.1 \\
\hline
\end{tabular}

\section{Conclusions}

In conclusion, native sheep from three different areas showed similar performance. Highest birth weight and wool production was in Coastal sheep but better reproductive performance was in Barind sheep.

\section{References}

Banerjee R 2008: Conservation and in situ development of a prolific indigenous sheep in the Sundarban and Sagar Island. PhD Thesis, University of Calcutta, Koltata, West Bengal, India. 
Banerjee GC 1989: A Text book of Animal Husbandry. $6^{\text {th }}$ edn. Oxford and IBH publishing Co. Pvt. Ltd., New Delhi, India.

BBS 2008: Bangladesh Bureau of Statistics. Planning Division, Ministry of Planning. Government of the People's Republic of Bangladesh, Dhaka, Bangladesh.

Bhuiyan AKFH 2006: Livestock genetic resources in Bangladesh: Preservation and Management. International conference on livestock services, Chinese Academy of Agricultural Science (CAAS), Beijing, China, April 16-20.

Bhuiyan AKFH, Curran MK 1991: Effect of age and year on the prolificacy of Romney marsh Sheep. Bangladesh Journal of Animal Science 20 49-54.

Bose S, Duttsgupta R, Maitra DN 1999: Phenotypic characteristics and management practices of Bengal sheep. Indian Journal of Small Ruminants 15: 18-22.

Ghalsasi PM, Nimbkar BV 1993: The "garole"- microsheep of native, India. Animal Genetic Resources Information, United Nations Environment Program pp. 73 -79.

Gopal D, Prasad H 2007: Morphological characteristics, live weights and management practices of muzaffarnagari sheep in the home tract. The Indian Journal of Small Ruminants 13 27-30.

Husain SS, Amin MR 2003: Genetic resource conservation and utilization: participatory maintenance of animal Genetics resource at rural level in Bangladesh. Paper presented Genetic resource conservation, Bangladesh Livestock Research Institute, Savar Dhaka, Bangladesh.

Hoque MM, Mollah MAU 1972: A survey on the prevalence of lice in sheep and goats of Dhaka and Mymensingh district, Bangladesh. Bangladesh Veterinary Journal 6 21-24.

Khan BB, Iqbal A, Mustafa MI 2003: Sheep and Goat Production. Department of Livestock Management, University of Agriculture, Faisalabad, Pakistan, pp. 21.

Mukherjee TK 2000: Final Consultancy Report on Goat and Sheep Production. Agriculture Research Management Project (BLRI Part) IDA, Credit No. 2815 BD, Bangladesh Livestock Research Institute, Savar, Dhaka-1341, Bangladesh.

Nimbkar C, Ghalsasi PM, Walkden-Brown SW, Kahn LP 2002: Breeding program for the genetic improvement of Deccani sheep of Maharashtra, India. $7^{\text {th }}$ World Congress of Genetics Applied to Livestock Production, Montpellier, France. August 19-23.

Nooruddin M, Miah MI, Miah MA, Pandit KK, Kamaruddin KM 1988: Prevalence and concurrence of skin diseases of sheep in Bangladesh. The Bangladesh Veterinarian 5 48-53.

Pan S, Sahoo AK 2003: Garole Sheep, Report of Ad-Hoc Research Scheme on survey evaluation of Garole sheep in sundarban area of West Bengal. West Bengal University of Agriculture and Fisheries Science, Mohanpur, West Bengal, India.

Pan S, Sahoo AK, Tantia MS Ahlawat SPS 2004: Garole Sheep, NATP (MM) on Animal Genetic resource bio-diversity. West Bengal University of Agriculture and Fisheries Science (WBUAFS), Mohanpur and Kolkata, West Bengal and NBAGR, Karnal, Haryana, India.

Piper LR, Bindon BM 1996: The Boroola Merino. In Prolific Sheep, Fahmy MH (Eds.), CAB International, Wallingford, United Kingdom, pp. 152-160. 
Poonia JS 2008: Reproductive performance of Munjal sheep. The Indian Journal of Small Ruminants 14 121-123.

Prasad J 1997: Goat, Sheep and Pig Production and Management. Kalyani Publishers, New Delhi, India.

Rahman MM, Huq MA 1976: A comparative study of gestation period, prolificacy and lambing interval of native and upgraded Lohi sheep. Bangladesh Veterinary Journal 10 31-35.

Sani RA, Hsiung KW, Najib MAM, Hassan AW, Hamid MA, Jilun M 1999: Optimizing sheep production under oil palm. Paper presented National Congress on Animal Health and Production, Kuching, Malaysia.

Sharma RC, Arora AL, Narula HK and Singh RN 1999: Characteristics of Garole sheep in India, AGRI, 26 57-64.

Singh RN, Bohra SDJ 1996: Garole Sheep: A profile (Bengal breed of sheep locally known as Garole). The Indian Journal of Small Ruminants 2 38-43.

Sultana N, Hossain SMJ, Chowdhury SA, Hassan MR, Ershaduzzaman M 2010: Effects of age on intake, growth, nutrient utilization and carcass characteristics of castrated native sheep. The Bangladesh Veterinarian 27 62-73. 